\title{
A COMPARATIVE ANALYSIS OF POLISH AND CZECH INTERNATIONAL NEW VENTURES
}

\author{
Danik L., Kowalik, I., Král, P. ${ }^{1}$
}

The goal of this paper is to compare the characteristics of Polish and Czech companies which follow the Born Global internationalization model. More concretely, the analysis aims to discover the differences or similarities in terms of the internationalization paths of Polish and Czech SMEs in the characteristics of their managers in terms of the so-called "international vision" and in their innovativeness level. The introductory part of article provides a description of this internationalization model and the International New Ventures traits (INV) and summarizes the recent studies on this topic conducted in Poland and Czech Republic. In the empirical part, the International New Ventures from the two countries are compared. The Polish sample includes 105 companies which were surveyed with use of computer assisted telephone interviews in autumn 2014. For the Czech Republic, the sample consists of 54 small and medium-sized companies, which were surveyed using the computer assisted web interviews from November 2013 till January 2014. The surveyed companies in both countries fulfilled the definition of Born Globals. Descriptive statistics, cross-tabulation analysis and non-parametric tests are applied to accomplish the goals of the paper.

Keywords: international new ventures; comparative analysis; Czech Republic; Poland JEL Classification: F23, M13, M16

\section{Introduction}

The topic of rapid internationalization of small and medium-sized companies has been attracting a lot of attention of researchers from around the globe. Over the past couple of years, dozens of research studies have been conducted to investigate this phenomenon. Despite the fact that this internationalization model can be very effective, especially for companies originating from emerging markets, the existing research covers mainly those SMEs that originate in developed countries, and the literature review revealed that there are just few studies analyzing the emerging markets of Central and Eastern Europe. Therefore, further research is needed in order to provide information specifically related to companies that originate from this region.

This study is an introductory analysis of the internationalization patterns of SME exporters originating from Poland and the Czech Republic, and it provides an overview of the important phenomenon of quick and early internationalization of enterprises from these two countries. The main goal of the study is to compare the internationalization patterns of Born Global or INV companies originating from these countries and to identify some commonalities or national differences.

Both investigated countries share a similar geographic location in Central Europe, they are members of the V4 group, both are neighbors of the biggest European market

An earlier version of this paper has been presented at the 16th International Joint Conference:

Central and Eastern Europe in the Changing Business Environment, Prague, 27th May 2016. 
(Germany) and they also share similar history (socialist regime in the second half of the 20th century followed by a transition stage which was successfully accomplished by EU entry in 2004). Therefore we can assume that there should be some common traits in the behavior of companies that originate from these two markets.

The paper starts with a review of the existing literature on the topic of the early internationalization of small and medium-sized enterprises on both, the global and the CEE level. Based on the results of the literature review the research questions are formulated. In the second part of the paper, the research methodology is introduced including a description of the analyzed sample and the variables studied and the research results are introduced. Based on the research results and their discussion, conclusions are derived in the concluding part of the paper.

\section{Literature Review}

The internationalization of companies right after their inception (which was observed in the last few decades) has challenged traditional internationalization theories and triggered studies on the sources, characteristics and implications of this phenomenon (McDougall, Shane \& Oviatt, 1994; Gabrielsson et al., 2008). In contrast to the firms internationalizing according to the Uppsala model (Johanson \& Vahlne, 1977), the companies referred to as International New Ventures - INVs (McDougall, Shane \& Oviatt, 1994), global startups (Oviatt \& McDougall, 1995), instant internationals (Fillis, 2001) or Born Globals (Knight \& Cavusgil, 1996; Gabrielsson et al., 2008) leapfrog some of the internationalization stages and are highly active in international markets nearly from the outset. The main traits of INVs are: the global vision, the international business competence of their managers and poverty of resources at the time of start-up (McDougall, Shane \& Oviatt, 1994; McDougall \& Oviatt, 1994; Knight \& Cavusgil, 2004). They rather apply a focus or differentiation strategy than a price leadership strategy (Knight \& Cavusgil, 2009) and their internationalization is often facilitated by innovations (Rennie, 1993; Madsen \& Servais, 1997; Knight \& Cavusgil, 2004).

Till now, most of the studies on INVs were conducted on companies from developed countries (Lamotte \& Colovic, 2015). The companies from emerging economies are still on the periphery of the scientific mainstream, although they tend to become stronger and stronger global players and entrepreneurship is one of the determinants of their success (Bruton, Ahlstrom \& Obloj, 2008).

Internationalization in the rapidly changing conditions caused by the systemic transformation in Poland was studied by Cieslik and Kaciak (2009), according to whom the transition context affects the international operations of privately-owned enterprises. A longitudinal study on 158000 Polish exporters in years 1989-2003 showed that most of them started exporting within the first three years of operation. The companies that focused initially on the domestic market did not engage in export later on.

Another study was conducted by Jarosiński (2013), who identified 32 Born Globals among 84 Polish internationalized firms. They operated on average in 8.6 markets, having an average share of foreign sales in total sales of $63 \%$. However, not all of them fully matched the Born Global definition, as most of them operated mostly on psychically close markets (Jarosiński, 2013). Nowiński and Nowara (2010) and Przybylska (2010) also identified Polish companies fulfilling the definition of INVs or Born Globals, proving that Polish companies 
followed the INV model at the same time as the companies from more developed countries.

A qualitative study followed by two quantitative studies of Polish INVs was conducted by Duliniec, Baranowska-Prokop, Kowalik, Sikora and Danik, indicating the specific traits of Polish INVs: their conciliatory approach, applying a hybrid strategy to gain competitive advantage and lack of marketing planning (Baranowska-Prokop \& Sikora, 2014; Danik \& Kowalik, 2015).

A study on 23577 firms from 27 countries in Central and Eastern Europe and Central Asia was conducted by Lamotte and Colovic (2015). Out of 1773 Polish companies in the sample, 84 were INVs with an average share of foreign sales in total sales of $54.15 \%$. The number of Czech companies in the sample was 808 with 69 INVs having $56.75 \%$ foreign sales share. The results of the analysis indicate some idiosyncrasies of the INVs from emerging countries; however, the hypotheses were tested for the whole sample, not for single countries. Paweta (2013) analyzed the possible determinants of early internationalization of companies originating from Visegrad countries (V4) and concluded that the Born Global internationalization model of was suitable for V4 countries due to the fact that all these countries are export-oriented, open economies which are relatively small in size (with the exception of Poland). They can use export opportunities in the Euro-zone, and with the exception of Slovakia, still kept their national currencies whose depreciation helped them to react quickly to the economic downturn in 2008-2009.

There are not many studies that investigated the INVs in the Czech Republic either. Zapletalová (2013) analyzed a representative sample of 204 internationally active Czech companies and found that the Born Global internationalization model can be relevant for Czech companies but the majority of the surveyed companies (98\%) followed the stage approach to internationalization, while only $2 \%$ followed the global approach. The study concluded that the main factor which influenced the decision to use the global approach to internationalization was the level of knowledge of foreign markets.

Dasan (2013) did not analyze Born Global companies specifically, but took a more general approach and investigated the internationalized SMEs in the Czech Republic and Russia. His findings clearly support the idea that internationally active SMEs perform significantly better than those who serve only the national market. The survey also revealed the importance of international activities for Czech SMEs $-73 \%$ of the surveyed Czech SMEs were active outside their home country (Dasan, 2013).

Kubíčková (2013) investigated the success factors of the internationalization of Czech SMEs in the ICT industry (which is considered as an industry that typically uses the Born Global approach to internationalization) and identified the top five success factors: existing contacts in foreign country, competitive advantage, high-skilled employees, foreign-market knowledge and a good marketing strategy.

The literature review revealed that the existing research on the topic of Born Globals and INVs in Poland and the Czech Republic is rather limited and thus there is a need for further investigation.

Based on the literature review and taking into account the similar historical and economic background of the V4 countries, we assumed that the variables and indicators of an early internationalization model (such as the "global" or "international" vision of the managers, "experience" and "openness", the scale of internationalization and the innovativeness) would be at similar levels in Polish and Czech enterprises. Thus we proposed the following research questions for this study: 
a. Do the characteristics of the Polish and Czech International New Ventures' managers differ in terms of "international vision"?

b. Do the Polish and Czech INVs differ in terms of internationalization path?

c. Do the Polish and Czech INVs differ in terms of innovativeness level and type?

\section{Methodology}

In this study we use the definition of an INV which was formulated by McDougall and Oviatt (2000) who defined an International New Venture as "a business organization that, from inception, seeks to derive significant competitive advantage from the use of resources and the sale of outputs in multiple countries". To operationalize the International New Ventures traits we use the Knight et al. (2004) criteria, referring to firms generating at least $25 \%$ of total sales abroad, 20 years old or younger and internationalizing within three years of founding.

In the empirical part, International New Venures from two V4 countries were compared. The Polish sample included SME companies, surveyed with use of the CATI (computer assisted telephone interviews) method in September and October 2014. The commercial database Bisnode updated at the end of 2013 and containing information about companies operating in Poland, served as a sampling frame. The firms were drawn out of the population of 19594 existing and active Polish firms with 10-249 employees, belonging to the Industrial Processing (Manufacturing) section " $C$ " of the Polish Classification of Activity. A randomized algorithm in the software for telephone surveying was used to select the respondents by a qualified market-research agency. 233 SMEs were selected for the study; 105 fulfilled the criteria of Born Global companies. Concretely, they were Polish-based and owned SMEs, founded after 1990, which had reached at least a 25\% share of export sales in the total turnover, internationalized within three years from their establishment and obtained a $25 \%$ share of exports in total sales volume during three years after the beginning of their internationalization.

The Czech sample consisted of companies of all sizes (in terms of turnover and the number of employees) from a commercial database MERK, which provided contacts to more than 17000 companies from all industries. The survey was conducted from November 2013 till January 2014 using the CAWI (computer assisted web interviews) method (besides app. 10 interviews which were conducted in person in November 2013). Altogether 590 valid responses were obtained (response rate around 4\%). Out of these responses, only SMEs were considered for further investigation if they fulfilled the above mentioned criteria of internationalization in the early stage of development, had Czech ownership and were established after 1990. Thus a sample of 54 companies was analyzed further. SPSS statistical software was used for calculations and analysis.

The mean level of employment in the Polish INVs was slightly lower than in the studied Czech INVs (44 pers. vs. 60 pers.; no significant difference in the variable's distribution). Moreover, the studied Polish companies were significantly younger (mean age of 10.5 years), than the Czech ones (18.9 years, difference significant at $p=0.01-$ see tables 1 and 2). 
Table 1 | Mean employment and age vs. the origin of the studied companies

\begin{tabular}{|c|c|c|c|}
\hline \multicolumn{2}{|c|}{ Country of origin } & \multirow{2}{*}{$\begin{array}{c}\text { No of employees } \\
44.1\end{array}$} & \multirow{2}{*}{$\begin{array}{c}\text { Company age at time } \\
\text { of interview }\end{array}$} \\
\hline \multirow{3}{*}{ Poland } & Mean & & \\
\hline & $\mathbf{N}$ & 92 & 105 \\
\hline & Std. dev. & 38.4 & 6.3 \\
\hline \multirow{3}{*}{ Czech Republic } & Mean & 60.8 & 18.9 \\
\hline & $\mathbf{N}$ & 54 & 54 \\
\hline & Std. dev. & 57.1 & 4.9 \\
\hline \multirow{3}{*}{ Total } & Mean & 50.3 & 13.4 \\
\hline & $\mathbf{N}$ & 146 & 159 \\
\hline & Std. dev. & 46.7 & 7 \\
\hline
\end{tabular}

Source: authors

Table 2 | Size and activity type of the studied companies vs. their origin

\begin{tabular}{|c|c|c|c|c|}
\hline & \multicolumn{2}{|c|}{ Origin of the company } & \multirow[b]{2}{*}{ Total } \\
\hline & & Poland & $\begin{array}{c}\text { Czech } \\
\text { Republic }\end{array}$ & \\
\hline \multicolumn{5}{|c|}{ Size of the company } \\
\hline \multirow{2}{*}{10 - 49 employees } & No of answers & 69 & 35 & 104 \\
\hline & $\%$ of sample & $65.7 \%$ & $64.8 \%$ & $65.4 \%$ \\
\hline \multirow{2}{*}{50 - 249 employees } & No of answers & 36 & 19 & 55 \\
\hline & $\%$ of sample & $34.3 \%$ & $35.2 \%$ & $34.6 \%$ \\
\hline \multicolumn{5}{|l|}{ Activity type } \\
\hline Manufacturing & $\begin{array}{l}\text { No of answers } \\
\% \text { of sample }\end{array}$ & $\begin{array}{r}105 \\
100.0 \%\end{array}$ & $\begin{array}{r}30 \\
55.6 \%\end{array}$ & $\begin{array}{r}135 \\
84.9 \%\end{array}$ \\
\hline Services & $\begin{array}{l}\text { No of answers } \\
\% \text { of sample }\end{array}$ & $\begin{array}{r}0 \\
0.0 \%\end{array}$ & $\begin{array}{r}24 \\
44.4 \%\end{array}$ & $\begin{array}{r}24 \\
15.1 \%\end{array}$ \\
\hline \multirow{2}{*}{ Total } & No of answers & 105 & 54 & 159 \\
\hline & $\%$ of sample & $100.0 \%$ & $100.0 \%$ & $100.0 \%$ \\
\hline
\end{tabular}

Source: authors 
Among the Polish INVs, the main activity types were: food production, metal goods' production, machinery and tools (not classified elsewhere), rubber and artificial fiber goods' production, furniture. Among the Czech INVs the main activity types were: manufacturing, construction, wholesale and retail trade, information and communication. Because of the two-tier structure of the Czech sample (i.e. split into manufacturing and services), we have checked for differences in distribution of studied variables among the Czech manufacturers and service providers. The non-parametric tests showed that both types of Czech companies were similar when it comes to the distribution of studied variables, apart from "experience of the managers" and "innovativeness level". Thus, we ran additional comparisons of subgroups of Czech companies, to the Polish sample, for those variables.

Table 3 | Classification of industries represented by the studied companies vs. their origin

\begin{tabular}{|c|c|c|c|c|}
\hline & & \multicolumn{2}{|c|}{ Country of origin } & \multirow[b]{2}{*}{ Total } \\
\hline & & Poland & $\begin{array}{l}\text { Czech } \\
\text { Republic }\end{array}$ & \\
\hline \multirow{2}{*}{ low tech } & No. of answers & 37 & 4 & 41 \\
\hline & $\%$ of sample & $35.2 \%$ & $7.5 \%$ & $25.9 \%$ \\
\hline \multirow{2}{*}{ medium low tech } & No. of answers & 27 & 26 & 53 \\
\hline & $\%$ of sample & $25.7 \%$ & $49.1 \%$ & $33.5 \%$ \\
\hline \multirow{2}{*}{ medium high tech } & No. of answers & 19 & 20 & 39 \\
\hline & $\%$ of sample & $18.1 \%$ & $37.7 \%$ & $24.7 \%$ \\
\hline \multirow{2}{*}{ high tech } & No. of answers & 4 & 3 & 7 \\
\hline & $\%$ of sample & $3.8 \%$ & $5.7 \%$ & $4.4 \%$ \\
\hline \multirow{2}{*}{$n / a$} & No. of answers & 18 & 0 & 18 \\
\hline & $\%$ of sample & $17.1 \%$ & $0.0 \%$ & $11.4 \%$ \\
\hline \multirow{2}{*}{ Total } & No. of answers & 105 & 53 & 158 \\
\hline & $\%$ of sample & $100.0 \%$ & $100.0 \%$ & $100.0 \%$ \\
\hline
\end{tabular}

Source: authors

Despite the differences in types of activity of the Czech and Polish companies, the non-parametric Mann-Whitney $U$ test showed no significant difference in the classification of industries, regarding the technological advancement level, of the companies coming from different countries (table $3, \mathrm{p}=0.208$ ). 


\section{4. $\quad$ Studied Variables}

"Global" or "international vision" comprising such traits as international experience, a certain "mental model" relating to openness towards foreign markets and the ability to spot opportunities are attributed to managers of Born Global companies (Rasmussan et al., 2001; Andersson \& Wictor, 2003). These managerial traits have been associated with early and quick foreign expansion also in some recent Polish studies (Kowalik, 2014).

Therefore, we have decided to check if companies originating from Central Europe in the presented study also display such traits. As indicators of international vision we have used the variables: "experience", and "openness", of which the second was measured slightly differently in both samples. In the Polish sample, the managers were asked to indicate their opinion on a 5-point semantic scale ranging from "Our company treats foreign markets as a priority" to "Our company treats the Polish market as a priority". As for experience, in the Polish sample, the managers were asked to indicate their opinion on the 5-point semantic scale ranging from: "The management has considerable experience in doing business on international markets" to: "The management has no experience in doing business on international markets". Whereas in the Czech sample, the managers were asked to mention their attitude towards internationalization regarding the criteria as: "international openness" and "experience relating to international markets" on 5-point scales ranging from "very low" to "very high".

In the second part of analysis, the internationalization path applied by the studied companies was studied. The internationalization path indicates the specificity of foreign expansion, in terms of its speed, scope, scale and in terms of the entry mode applied (Wach, 2014; Kuivalainen et al., 2012; Cieslik \& Kaciak, 2009).

In the presented study, the scale of internationalization was measured as the percentage of revenues coming from export activity. The speed of internationalization was measured as the time from establishment to first foreign market entry. The scope of internationalization was measured on the basis of geographical distance of export markets and the percentage of revenues coming from different regions.

Innovativeness is one of the key dimensions of entrepreneurship (Covin \& Miller, 2014). Moreover, according to results of empirical studies (e.g. Mort et al., 2012) innovativeness of the INVs accompanies their success. In our study, we have analyzed the Polish INVs' innovativeness by asking (a) if they have introduced any innovations in their products or processes; (b) examples of such innovations (in distribution and promotion) were cited; and (c) the speed of innovation introduction was assessed. The Czech INVs' innovativeness was measured by asking (a) if the company has introduced innovations in the last 3 years, (b) what type of innovations was introduced; and (c) what the degree (local, regional, national, global) of innovativeness was.

\section{Results}

\section{a. International Vision}

The characteristic traits of managers of the International New Ventures from the two countries were first compared (see tables 4 and 5). 
Table 4 | Experience of the INV companies' managers in dealing with international markets vs. origin of the company

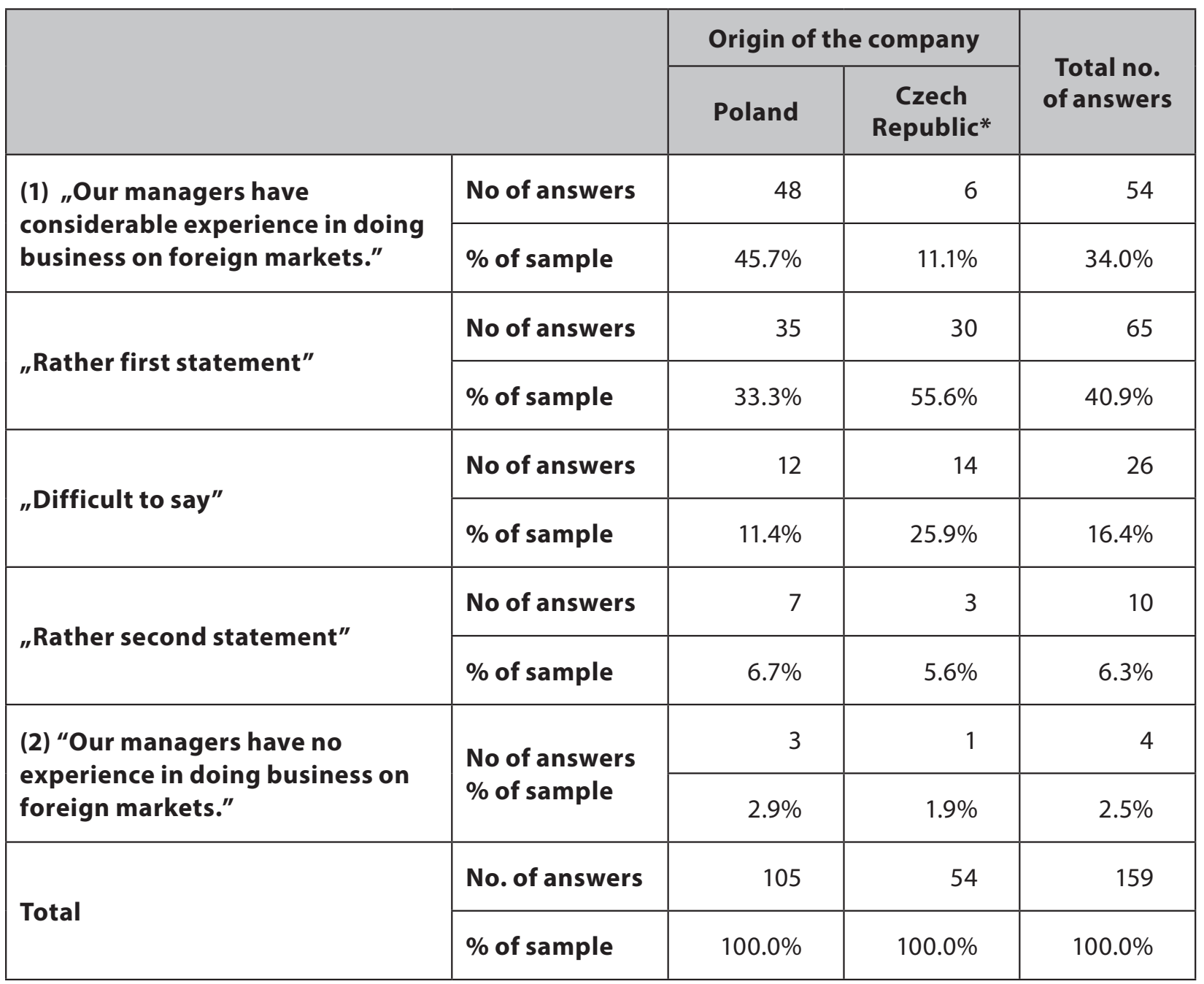

Source: authors

Note: for the Czech companies answers on a 5-point Likert scale ranging from "very low experience relating to international markets" to "very high experience" were recoded and analyzed respectively.

Regarding the first of the international vision dimensions - international experience, the Mann-Whitney U Test showed that the hypothesis about the same distribution of variable in Czech and Polish samples is rejected $(p=0.01)$. We have further checked that this variable's distribution differs among the $\mathrm{CZ}$ manufacturing companies and service providers; therefore, we additionally compared the experience levels of only the manufacturing companies from both countries, to find that they also differ significantly (the Mann-Whitney U Test showed differences significant at $\mathrm{p}=0.01$ ).

Regarding the second of international vision dimensions - i.e. openness to the foreign markets, the Mann-Whitney U Test showed that the hypothesis about the same distribution of this variable in Czech and Polish samples is rejected $(\mathrm{p}=0.002)$. 
Table 5 | Openness of the INV companies' managers to the foreign markets vs. origin of the company

\begin{tabular}{|c|c|c|c|c|}
\hline & & Origin $c$ & company & \\
\hline Statemen & & Poland & Czech & answers \\
\hline „Our company treats & No of answers & 64 & 12 & 76 \\
\hline priority" & $\%$ of sample & $61.0 \%$ & $22.2 \%$ & $47.8 \%$ \\
\hline „Foreign markets are & No of answers & 20 & 34 & 54 \\
\hline rather our priority" & $\%$ of sample & $19.0 \%$ & $63.0 \%$ & $34.0 \%$ \\
\hline & No of answers & 10 & 6 & 16 \\
\hline & $\%$ of sample & $9.5 \%$ & $11.1 \%$ & $10.1 \%$ \\
\hline „Rather Polish market is & No of answers & 9 & 1 & 10 \\
\hline our priority" & $\%$ of sample & $8.6 \%$ & $1.9 \%$ & $6.3 \%$ \\
\hline "Our company treats & No of answers & 2 & 1 & 3 \\
\hline Polish market as priority" & $\%$ of sample & $1.9 \%$ & $1.9 \%$ & $1,9 \%$ \\
\hline & No. of answers & 105 & 54 & 159 \\
\hline Totat & $\%$ of sample & $100.0 \%$ & $100.0 \%$ & $100.0 \%$ \\
\hline
\end{tabular}

Source: authors

*Note: for the Czech companies answers on a 5-point Likert scale ranging from "very low international openness" to "very high international openness" were recoded and analyzed respectively.

In case of the variable "Openness to foreign markets", the Czech sample was homogenous between manufacturing and service companies, so it was compared with the Polish sample as a whole.

Summing up, both elements of "international vision" are significantly differentiated among the Czech and Polish International New Ventures. There are more Polish companies declaring that foreign markets are definitely a priority for them and that they have considerable experience in dealing with foreign clients. However, the numbers of companies in both samples declaring very weak "international vision" are similar.

\section{b. Internationalization Path}

Regarding the first dimension of internationalization - its scale expressed as the share of export revenues in total revenues, the Mann-Whitney U Test showed that the hypothesis about the same distribution of variable in the Czech and Polish samples is supported $(p=0.154)$. However, as shown in table 6, there are slightly more "intensive exporters" (i.e. with an export share of $50 \%$ or more of total revenues) among the studied Polish INVs than among the Czech ones. 
Table 6 | Share of export in revenue vs. origin of the company

\begin{tabular}{|l|l|c|c|c|}
\hline \multirow{2}{*}{$\begin{array}{l}\text { Share of revenues obtained from export in } \\
\text { total revenues }\end{array}$} & \multicolumn{2}{|c|}{ Origin of the company } & \multirow{2}{*}{ Total } \\
\cline { 3 - 5 } & Poland & $\begin{array}{c}\text { Czech } \\
\text { Republic }\end{array}$ & \\
\hline \multirow{3}{*}{$\mathbf{2 5 - 5 0 \%}$} & No of answers & 37 & 23 & 60 \\
\cline { 2 - 5 } & \% of sample & $35.2 \%$ & $42.6 \%$ & $37.7 \%$ \\
\hline \multirow{3}{*}{$\mathbf{5 1 - 7 5 \%}$} & No of answers & 18 & 15 & 33 \\
\cline { 2 - 5 } & \% of sample & $17.1 \%$ & $27.8 \%$ & $20.8 \%$ \\
\hline \multirow{3}{*}{$\mathbf{7 6 - 1 0 0 \%}$} & No of answers & 50 & 16 & 66 \\
\cline { 2 - 5 } & \% of sample & $47.6 \%$ & $29.6 \%$ & $41.5 \%$ \\
\hline \multirow{3}{*}{ Total } & No of answers & 105 & 54 & 159 \\
\cline { 2 - 5 } & \% of sample & $100.0 \%$ & $100.0 \%$ & $100.0 \%$ \\
\hline
\end{tabular}

Source: authors

Regarding the second dimension of internationalization speed, it can be seen from table 7 that $81 \%$ of the Polish INVs internationalized within the first year of existence, while in the Czech sample, the figure equals 55.6\%. The Mann-Whitney U Test showed that the hypothesis about the same distribution of this variable in the Czech and Polish samples is rejected $(\mathrm{p}=0.002)$.

Table 7 | Export beginning vs. origin of the company

\begin{tabular}{|l|l|c|c|c|}
\hline \multirow{2}{*}{\begin{tabular}{l}
\multirow{2}{*}{$\begin{array}{l}\text { Time of export beginning (no. of years } \\
\text { from inception) }\end{array}$} \\
\cline { 3 - 5 }
\end{tabular}} & Poland & $\begin{array}{c}\text { Country of origin } \\
\text { Republic }\end{array}$ & \multirow{2}{*}{ Total } \\
\hline \multirow{3}{*}{ Up to 1 year } & No of answers & 85 & 30 & 115 \\
\cline { 2 - 5 } & \% of sample & $81.0 \%$ & $55.6 \%$ & $72.3 \%$ \\
\hline \multirow{3}{*}{ From 1 -2 years } & No of answers & 12 & 18 & 30 \\
\cline { 2 - 5 } & \% of sample & $11.4 \%$ & $33.3 \%$ & $18.9 \%$ \\
\hline \multirow{3}{*}{ From 2 - 3 years } & No of answers & 8 & 6 & 14 \\
\cline { 2 - 5 } & \% of sample & $7.6 \%$ & $11.1 \%$ & $8.8 \%$ \\
\hline \multirow{2}{*}{ Total } & No of answers & 105 & 54 & 159 \\
\cline { 2 - 5 } & \% of sample & $100.0 \%$ & $100.0 \%$ & $100.0 \%$ \\
\hline
\end{tabular}

Source: authors 
Regarding the third dimension of internationalization - its scope, the numbers of studied Polish companies internationalizing only within Europe (c.a. $49 \%$ of the sample) are much higher than among Czech companies (app. 24\% of the sample). However, the distribution of revenues coming from these markets is quite different (table 8 , the hypothesis about the same distribution of this variable in the Czech and Polish samples was rejected, $p=0.01$ ).

Table 8 | Revenues from the target market vs. origin of the company

\begin{tabular}{|l|c|c|}
\hline \multirow{2}{*}{ Target market } & \multicolumn{2}{|c|}{ Mean revenue level from the given market (in \%) } \\
\cline { 2 - 3 } & Poland (n=105) & Czech Republic (n=54) \\
\hline V4 markets & 4.6 & 35.4 \\
\hline V4 and CEEC markets & 7.8 & 28 \\
\hline other EU markets (non-CEEC) & 62.7 & 13.7 \\
\hline non-EU markets & 40.7 & 28.7 \\
\hline
\end{tabular}

Source: authors

Table 9 | Entry mode vs. origin of the company

\begin{tabular}{|c|c|c|c|c|}
\hline \multirow{2}{*}{\multicolumn{2}{|c|}{ Most advanced entry mode chosen* }} & \multicolumn{2}{|c|}{ Origin of the company } & \multirow{3}{*}{$\begin{array}{r}\text { Total } \\
4\end{array}$} \\
\hline & & \multirow{2}{*}{$\begin{array}{r}\text { Poland } \\
2\end{array}$} & \multirow{2}{*}{$\begin{array}{c}\begin{array}{c}\text { Czech } \\
\text { Republic }\end{array} \\
2\end{array}$} & \\
\hline \multirow{2}{*}{ Indirect export } & No of answers & & & \\
\hline & $\%$ of sample & $1.9 \%$ & $3.8 \%$ & $2.5 \%$ \\
\hline \multirow{2}{*}{$\begin{array}{l}\text { Direct export from the } \\
\text { country to the client }\end{array}$} & No of answers & 65 & 0 & 65 \\
\hline & $\%$ of sample & $61.9 \%$ & $0.0 \%$ & $41.1 \%$ \\
\hline \multirow{2}{*}{$\begin{array}{l}\text { Direct export with } \\
\text { intermediaries }\end{array}$} & No of answers & 38 & 10 & 48 \\
\hline & $\%$ of sample & $36.2 \%$ & $18.9 \%$ & $30.4 \%$ \\
\hline \multirow{2}{*}{$\begin{array}{l}\text { More advanced modes } \\
\text { of entry (contractual, } \\
\text { hierarchical) }\end{array}$} & No of answers & 0 & 41 & 41 \\
\hline & $\%$ of sample & $0.0 \%$ & $77.4 \%$ & $25.9 \%$ \\
\hline \multirow{2}{*}{ Total } & No of answers & 105 & 53 & 158 \\
\hline & $\%$ of sample & $100.0 \%$ & $100.0 \%$ & $100.0 \%$ \\
\hline
\end{tabular}

Source: authors

*Note: For companies applying more than one entry mode type at once, only the most advanced modes were included. 
For the Polish-based INVs on average the revenues coming from V4 and Central and Eastern European Countries (CEEC) constitute around $7.8 \%$ of all revenues, while for Czech INVs this rate is around 35.4\%. Regarding the more distant, "old EU member" countries - on average the Polish-based INVs get two-thirds of revenue from them, while the Czech ones - less than one-third. Moreover, 18 of the Polish INVs are even more internationalized, as they get on average $40.7 \%$ of revenues from markets outside the EU. For the Czech companies the mean level of revenues from markets outside the EU is $13.7 \%$.

Finally, regarding the chosen entry modes, we found that all the studied Polish INVs chose export entry (table 9 - almost $62 \%$ of companies prefer direct export from home to the foreign client). On the other hand, the studied Czech INVs preferred more advanced entry modes - over $77 \%$ applied them.

Among the main advanced entry modes were the contractual modes (contract manufacturing - 28 companies), moreover 14 companies admitted they had a foreign branch or a wholly owned subsidiary. Other types of advanced entry modes (e.g. franchising or licensing) were represented sporadically.

\section{c. Innovativeness of the Companies}

Finally, the innovativeness was compared in both samples, i.e. both the declared level (intensity) and types of introduced innovations were analyzed.

Table 10 | Innovations intensity vs. origin of the company

\begin{tabular}{|c|c|c|c|c|}
\hline \multirow{2}{*}{\multicolumn{2}{|c|}{ Innovations intensity }} & \multicolumn{2}{|c|}{ Origin of the company } & \multirow{3}{*}{$\begin{array}{r}\text { Total } \\
28 \\
17.6 \%\end{array}$} \\
\hline & & \multirow{2}{*}{$\begin{array}{r}\text { Poland } \\
19 \\
18.1 \%\end{array}$} & \multirow{2}{*}{$\begin{array}{c}\begin{array}{c}\text { Czech } \\
\text { Republic }\end{array} \\
9 \\
16.7 \%\end{array}$} & \\
\hline No innovations declared & $\begin{array}{l}\text { No of answers } \\
\% \text { of sample }\end{array}$ & & & \\
\hline $\begin{array}{l}\text { Low innovators } \\
\text { ( } 1 \text { type declared) }\end{array}$ & $\begin{array}{l}\text { No of answers } \\
\% \text { of sample }\end{array}$ & $\begin{array}{r}50 \\
47.6 \%\end{array}$ & $\begin{array}{r}23 \\
42.6 \%\end{array}$ & $\begin{array}{r}73 \\
45,9 \%\end{array}$ \\
\hline $\begin{array}{l}\text { Medium innovators } \\
\text { ( } 2 \text { types declared) }\end{array}$ & $\begin{array}{l}\text { No of answers } \\
\% \text { of sample }\end{array}$ & $\begin{array}{r}24 \\
22.9 \%\end{array}$ & $\begin{array}{r}14 \\
25.9 \%\end{array}$ & $\begin{array}{r}38 \\
23.9 \%\end{array}$ \\
\hline $\begin{array}{l}\text { High innovators } \\
\text { ( } 3 \text { types declared) }\end{array}$ & $\begin{array}{l}\text { No of answers } \\
\% \text { of sample }\end{array}$ & $\begin{array}{r}12 \\
11.4 \%\end{array}$ & $\begin{array}{r}8 \\
14.8 \%\end{array}$ & $\begin{array}{r}20 \\
12.6 \%\end{array}$ \\
\hline \multirow{2}{*}{\multicolumn{2}{|c|}{ Total }} & 105 & 54 & 159 \\
\hline & & $100.0 \%$ & $100.0 \%$ & $100.0 \%$ \\
\hline
\end{tabular}

Source: authors

As table 10 shows, there were similar percentages of companies with the same innovation intensity among Polish and Czech INVs (Mann-Whitney U Test, $p=0.456$ ). In addition, because this variable was differently distributed in the $\mathrm{CZ}$ manufacturing and service companies, we performed the comparison of the CZ and PL manufacturing companies only. Again, there were similar percentages of companies with the same innovation intensity among Polish and Czech manufacturing INVs (Mann-Whitney U Test, $p=0.517$ ). 
Further, we found that similar shares of both samples introduced process innovations (table 11), but in product innovations the Czech INVs are leaders (almost half of sample declared to introduce them), while the Polish INV companies are slightly better at introducing marketing innovations than the Czech ones.

Table 11 | Innovation types vs. origin of the companies

\begin{tabular}{|c|c|c|c|c|}
\hline & & Origin & ompany & \\
\hline Innovation types & & Poland & Czech & Total \\
\hline Product innovations & $\begin{array}{l}\text { No of answers } \\
\% \text { of sample }\end{array}$ & $\begin{array}{r}29 \\
27.6 \%\end{array}$ & $\begin{array}{r}26 \\
48.1 \%\end{array}$ & $\begin{array}{r}55 \\
34.6 \%\end{array}$ \\
\hline Process innovations & $\begin{array}{l}\text { No of answers } \\
\% \text { of sample }\end{array}$ & $\begin{array}{r}65 \\
61.9 \%\end{array}$ & $\begin{array}{r}33 \\
61.1 \%\end{array}$ & $\begin{array}{r}98 \\
61.6 \%\end{array}$ \\
\hline Marketing innovations & $\begin{array}{l}\text { No of answers } \\
\% \text { of sample }\end{array}$ & $\begin{array}{r}40 \\
38.1 \%\end{array}$ & $\begin{array}{r}16 \\
29.6 \%\end{array}$ & $\begin{array}{r}56 \\
35.2 \%\end{array}$ \\
\hline
\end{tabular}

Source: authors

\section{Discussion, Conclusions and Limitations}

In relation to the research questions set at the beginning of the paper, the following main conclusions can be drawn. Regarding question a) we found significant differences in the international vision dimensions, namely the Czech managers seem to have a lower experience and openness towards going abroad than the Polish ones. However, the apparent differences may be partially due to different "response styles" among Polish and Czech respondents (i.e. the Polish ones are more willing to point to the positive end of the scale, while the Czech ones to the middle). This difference in response style was identified e.g. by Johnson et al. (2005) who suggested that countries with a higher masculinity index and higher power distance index are more likely to select extreme answers when answering questionnaires. Poland scores higher than the Czech Republic on both dimensions; masculinity 64 vs. 57 and power distance 68 for Poland vs. 57 for the Czech Republic (Hofstede et al., 2010). This conclusion is also supported by the fact that there were almost equal shares of both samples displaying "low" or "very low" international vision dimensions. Even not taking into account this "response style effect", these Polish and Czech companies' results support the other empirical studies from highly developed countries, stating that INV managers have strong international vision, and it helps them in quick internationalization (Bell et al., 2003; Karra \& Phillips 2004).

Regarding question b) - among the Polish companies, there are many more "instant internationalizers" and the primary target for the Polish-based INVs are the "old EU member" markets. Besides, some of the studied Polish INVs obtain considerable shares of revenues coming from markets out of Europe (which according to some sources is an additional criterion to be named "Born Globals" (Gabrielsson et al., 2012). On the other hand, the primary market for the studied Czech INVs in terms of highest revenue level are the CEEC markets. Such an "expansion model" confirms the general export orientation of 
the Czech Republic, for which Germany is the most important export market, followed by Slovakia. Especially the position of Slovakia is worth mentioning because this country was just 23 years ago part of the same country as the Czech Republic (Czechoslovakia) and therefore, also due to similar language and still existent economic and personal connections, it is usually among the first markets considered for international expansion by the Czech companies. Similar ties exist also in the relationship with Germany, which is also the most important foreign investor in the country. Czech companies are often fully integrated into the production processes of German companies.

On the other hand, Czech entrepreneurs, as opposed to their Polish counterparts, cannot take advantage of the diaspora of their nationals in distant markets which can make their expansion to more distant markets more complicated.

Finally, regarding the research question c) - similar intensity of innovation activity was found in both samples; however, the product innovations were more important for the Czech companies. There is evidence from previous studies on the Polish INVs, that they emphasize product quality as their success factor; however, they introduce fewer innovations than their counterparts (Danik \& Kowalik, 2015). Also the available public reports show that the Czech companies are more innovative than the Polish ones (Innovative Entrepreneurship, 2015). The latest Global Entrepreneurship monitor for the Czech Republic suggests several reasons for the high innovativeness of the Czech Republic, such as the usage of newest technologies in companies, relatively high percentage of companies which operate in medium or high technologically advanced industry and also the relatively good protection of intellectual property (Lukeš \& Jakl, 2011).

To conclude, we found some common traits, but also important differences within the Polish and Czech companies following the Born Global internationalization model. The differences point mainly to the different speed and scope of internationalization of the studied INVs.

They show that rather there is no "regional" model of accelerated internationalization in the V4 countries. Czech and Polish managers seem to share the same level of international vision but, on the other hand, the Polish INVs expand to more distant markets while Czech INVs typically start their expansion in the neighboring countries within the CEE region. The study also confirmed the results of previous studies that Czech companies are more innovative in terms of product innovation than the Polish companies but the general intensity of innovativeness was similar for companies from both countries.

The results of this study should be interpreted bearing several limitations in mind. The first limitation is that the study investigated two V4 countries only. The results proved that there are some differences comparing Poland and the Czech Republic and therefore one can expect that the results for other CEE countries can differ as well. Another limitation was caused by the relatively small size of the sample in both countries (159 companies were analyzed). By increasing the size of the sample the research can deliver slightly different results. The last limitation was caused by the nature of the study which concentrated on quantitative results solely but did not study the motivations and did not aim to explain qualitatively the identified differences.

Thus further research should concentrate on investigation of other markets within the Central Europe. Also further research is needed to understand the reasons behind the differences of internationalization paths of the INVs in both countries in detail. 


\section{References}

Andersson, S., \& Wictor, I. (2003), Innovative internationalization in new firms: Born Globals -the Swedish case. Journal of International Entrepreneurship, 1(3), 249-276.

Cieslik, J., \& Kaciak, E. (2009). The speed of internationalization of entrepreneurial start-ups in a transition environment. Journal of Development Entrepreneurship, 14(4), 375-392.

Covin, J. G., \& Miller, D. (2014). International Entrepreneurial Orientation: Conceptual Considerations, Research Themes, Measurement Issues, and Future Research Directions. Entrepreneurship Theory and Practice, Jan., 11-44.

Baranowska-Prokop, E., \& Sikora, T. (2014). Relationship Between Competitive Strategies and the Success Perception of Polish Born Globals. International Journal of Management and Economics, 43, 94-113.

Bell, J. D., McNaughton, R., Young S., \& Crick D. (2003). Towards an integrative model on small firm internationalization. Journal of International Entrepreneurship, 1(4), 339-362.

Bruton, G. D., Ahlstrom D. \& Obloj K. (2008). Entrepreneurship in Emerging Economies: Where We Are Today and Where Should the Research Go in the Future. Entrepreneurship Theory and Practice, 32(1), 1-14.

Danik, L., \& Kowalik, I. (2015). Success factors and development barriers perceived by the Polish Born Global companies. Empirical study results. Journal of East European Management Studies, 20(3), 360-390.

Dasan, P. (2013). Small and Medium Enterprise Assessment in Czech Republic and Russia Using Marketing Analytics Methodology. Central European Business Review, 2(4), 39-49.

Fillis, I. (2001). Small firm internationalization: an investigative survey and future research directions. Management Decision, 39(9), 767-783.

Gabrielsson, P., Gabrielsson, M. \& Seppälä, T. (2012). Marketing Strategies for Foreign Expansion of Companies Originating in Small and Open Economies: The Consequences of Strategic Fit and Performance. Journal of International Marketing, 20(2), 25-48.

Gabrielsson, M., Kirpalani, V. H. M., Dimitratos, P., Solberg, C. A. \& Zucchella, A. (2008). Born Globals: Propositions to help advance the theory. International Business Review, 17, 385-401.

Hofstede, G. H., Hofstede, G. J., Minkov, M. (2010). Cultures and Organizations: Software of the Mind, Intercultural Cooperation and its Importance for Survival. $3^{\text {rd }}$ edition. New York: McGraw-Hill.

Innovative entrepreneurship (2015). The revealed and hidden potential for innovation in Poland (2015). P. Zadura-Lichota (Ed.), Warsaw: Polska Agencja Rozwoju Przedsiębiorczości.

Jarosiński, M. (2013). Characteristics of Born Globals from a Transition Economy. Proceedings of the 39th Annual Conference of European International Business Academy (EIBA), Bremen.

Johanson, J., \& VahIne, J-E. (1977). The Internationalization Process of the Firm-A Model of Knowledge Development and Increasing Market Commitment. Journal of International Business Studies, 8(1), 23-32.

Johnson, T., Kulesa, P., Cho, Y. I., \& Shavitt, S. (2005). The Relation between Culture and Response Styles-Evidence from 19 Countries. Journal of Cross-Cultural Psychology, 36(2), 264-277.

Karra, N., \& Philips, N. (2004). Entrepreneurship goes global. Ivey Business Journal Online, Nov/Dec., Retrieved January 10, 2016, from http://iveybusinessjournal.com/publication/ entrepreneurship-goes-global/.

Knight, G., \& Cavusgil, S. T. (1996). The Born Global Firm: A Challenge to Traditional Internationalization Theory. Advances in International Marketing, 8, 11-26. 
Knight, G., \& Cavusgil, S. T. (2004). Innovation, organizational capabilities, and the bornglobal Firm. Journal of International Business Studies, 35(2), 124-141.

Knight, G. A., Madsen, T. K., \& Servais P. (2004). An inquiry into born-global firms in Europe and the USA. International Marketing Review, 21(6), 645-665.

Knight, G., \& Cavusgil, S. T. (2009). Born Global firms: A new international enterprise. New York: Business Expert Press.

Kowalik I. (2014). Cechy kierownictwa przedsiębiorstw wcześnie umiędzynarodowionych -czynnik sukcesu na rynkach zagranicznych? Wyniki badań empirycznych, Gospodarka Materiałowa i Logistyka, 7(CD).

Kubíčková, L. (2013). Faktory úspěchu v internacionalizačním procesu MSP podnikajících v oblasti ICT. Acta academica karviniensia, 3, 119-128.

Kuivalainen, O., Saarenko, S., \& Sundquist, S, (2012). Internationalization patterns of small and medium-sized enterprises. International Marketing Review, 29(5), 448-465.

Lamotte, O., \& Colovic, A. (2015). Early Internationalization Of New Ventures From Emerging Countries: The Case of Transition Economies.M@n@gement, 18(1),8-30.

Lukeš, M., \& Jakl, M. (2011). Global Entrepreneurship Monitor-Podnikatelská aktivita v České Republice. Global Entrepreneurship Research Association.

Madsen, T. K., \& Servais, P. (1997). The internationalization of Born Globals: an evolutionary process?. International Business Review, 6(6), 561-583.

McDougall, P. P., \& Oviatt, B. M. (2000). International entrepreneurship: the intersection of two research paths. Academy of Management Journal, 43(5), 902-906.

McDougall, P. P., Shane, S., \& Oviatt, B. M. (1994). Explaining the formation of international new ventures: The limits of theories from international business research. Journal of Business Venturing, 9, 469-487.

Mort, G. S., Weerawardena, J., \& Liesh, P. (2012). Advancing entrepreneurial marketing: Evidence from Born Global firms. European Journal of Marketing, 46(3/4), 542-561.

Nowiński, W., \& Nowara, W. (2010). Stopniowa czy przyspieszona internacjonalizacja - analiza polskich prywatnych MŚP. Przegląd Organizacji, 12, 10-13.

Oviatt, B. M., \& McDougall, P. P. (1995). Global start-ups: Entrepreneurs on a worldwide stage. Academy of Management Executive, 9(2), 30-44.

Pawęta, E. (2013). The Determinants of Born Global Companies Emerging in Central European Countries. Entrepreneurial Business and Economic Review, 1(2), 41-50.

Przybylska, K. (2010). Born Global - nowa generacja małych polskich przedsiębiorstw. Gospodarka Narodowa, 7-8, 63-84.

Rasmussan, E. S., Madsen, T. K., \& Evangelista F. (2001). The founding of the Born Global company in Denmark and Australia: sensemaking and networking, Asia Pacific Journal of Marketing and Logistics, 13(3), 75-107.

Rennie, M. W. (1993). Born Global. McKinsey Quarterly, 4, 45-52.

Wach, K. (2014). Theoretical framework of the firm-level internationalization in Business studies. In A. Durendez \& K. Wach (Eds.), Patterns of Business internationalization in Visegrad Countries - in search of regional specifics (pp. 13-30). Cartagena: Universidad Politechnica de Cartagena.

Zapletalová, Š. (2013). International Management: The Approaches to the Internationalization Process of Entrepreneurial Activities of the Czech Companies. In Proceedings in GVW-the 1st Global Virtual Conference-Workshop. 


\section{Authors}

\section{Lidia Danik}

Institute of International Management and Marketing

Warsaw School of Economics, Poland

Idanik@sgh.waw.pl

\section{Izabela Kowalik}

Institute of International Management and Marketing

Warsaw School of Economics, Poland

izabela.kowalik@sgh.waw.pl

\section{Petr Kral}

Department of International Business

Faculty of International Relations

University of Economics, Prague, Czech Republic

kralp@vse.cz

The article is a result of the project financed by the University of Economics, Prague titled: Early internationalization of the Polish and Czech small and medium-sized enterprises - a comparative study, carried out in 2015/2016. The empirical research on Polish INVs was financed by the Statutory Fund of the Collegium of World Economy, Warsaw School of Economics in 2014/2015. 